\title{
Low-loss tunable all-in-fiber filter for Raman spectroscopy
}

\author{
Brunetti, Anna Chiara; Scolari, Lara; Lund-Hansen, Toke; Rottwitt, Karsten
}

Published in:

Proceedings of Optical Sensors 2011

Publication date:

2011

Document Version

Publisher's PDF, also known as Version of record

Link back to DTU Orbit

Citation (APA):

Brunetti, A. C., Scolari, L., Lund-Hansen, T., \& Rottwitt, K. (2011). Low-loss tunable all-in-fiber filter for Raman spectroscopy. In Proceedings of Optical Sensors 2011: OSA Technical Digest (CD) (pp. SWA3). Optical Society of America.

\section{General rights}

Copyright and moral rights for the publications made accessible in the public portal are retained by the authors and/or other copyright owners and it is a condition of accessing publications that users recognise and abide by the legal requirements associated with these rights.

- Users may download and print one copy of any publication from the public portal for the purpose of private study or research.

- You may not further distribute the material or use it for any profit-making activity or commercial gain

- You may freely distribute the URL identifying the publication in the public portal

If you believe that this document breaches copyright please contact us providing details, and we will remove access to the work immediately and investigate your claim 


\title{
Low-Loss Tunable All-in-Fiber Filter for Raman Spectroscopy
}

\author{
Anna Chiara Brunetti ${ }^{1}$, Lara Scolari $^{2}$, Toke Lund-Hansen ${ }^{1}$, Karsten Rottwitt $^{1}$ \\ 1. DTU Fotonik, Technical University of Denmark, Ørsteds Plads 343, DK-2800 Kgs. Lyngby, Denmark \\ 2. NKT Photonics A/S, Blokken 84, DK-3460 Birkerød, Denmark \\ acbr@fotonik.dtu.dk
}

\begin{abstract}
We show a novel in-line Rayleigh-rejection filter for Raman spectroscopy, based on a solid-core Photonic Crystal Fiber (PCF) filled with a high-index material. The device is low-loss and thermally tunable, and allows for a strong attenuation of the Rayleigh line at $532 \mathrm{~nm}$ and the transmission of the Raman lines in a broad wavenumber range.
\end{abstract}

(C) 2011 Optical Society of America

OCIS codes: $060.5295,300.6450$.

All-in-fiber Raman probes rely on the replacement of bulk-optics components with fiber components. The realization of a fiber-based notch filter for the rejection of the Rayleigh-scattered light is crucial. So far, fiber Bragg gratings have mainly been used [1]. The tunability of such gratings, $\sim 20 \mathrm{~nm}$ at telecom wavelengths [2], is not enough for Raman systems working at visible wavelengths where fluorescence correction is achieved by using a tunable laser [3].

Here we show a low-loss, highly tunable filter, based on a large mode area fiber (LMA-5, NKT Photonics A/S) filled with a high-index material (Immersion Liquid 5040, Cargille Laboratories). The resulting device exhibits spectral bandgaps and is suitable for integration in a 532nm Raman system as an in-line filter. To our knowledge, this is the first realization of a Rayleigh-rejection filter by exploiting the photonic bandgap effect in a filled solid-core PCF. At room temperature (RT), the FWHM bandwidth is $\sim 143 \mathrm{~nm}$, and the insertion loss is $0.3 \mathrm{~dB}$. The thermal tunability from RT to $70^{\circ} \mathrm{C}$ is $32 \mathrm{~nm}$, as shown in Fig. 1 . At $70^{\circ} \mathrm{C}$, the extinction ratio at $532 \mathrm{~nm}$ is $20.5 \mathrm{~dB}$.
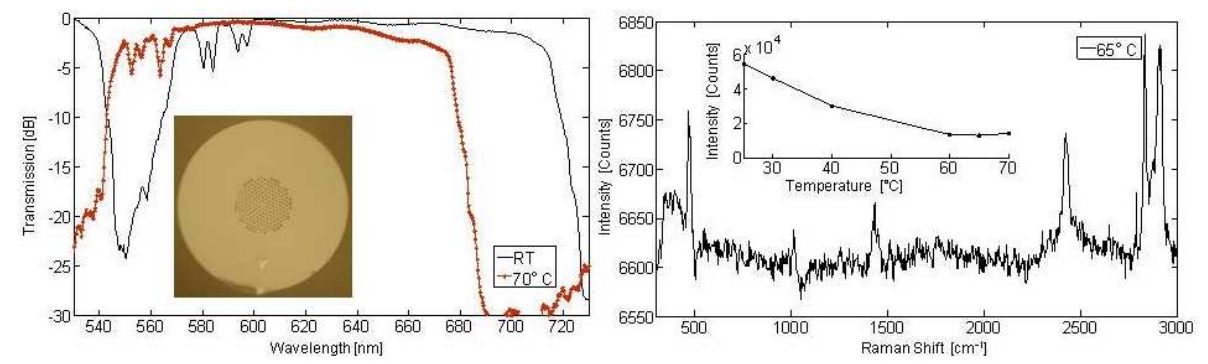

Fig.1 (Left) Transmission spectra of the device at RT $\left(22^{\circ} \mathrm{C}\right)$ and at $70^{\circ} \mathrm{C}$, both normalized to the spectrum of the unfilled fiber; (Right) Raman spectrum of cyclohexane transmitted through the filled fiber, at $65^{\circ} \mathrm{C}$. Inset: attenuation of the Rayleigh line due to the tuning of the filter.

In Fig. 1 we show the Raman spectrum of cyclohexane measured in a $90^{\circ}$ configuration by using a $532 \mathrm{~nm}$ excitation laser, in conjunction with the fabricated filtering device. The strongest lines $\left(2938,2923\right.$ and $\left.2852 \mathrm{~cm}^{-1}\right)$ are clearly identifiable. As shown in the inset, the application of this device to a $532 \mathrm{~nm}$ Raman system provides a strong attenuation of the Rayleigh-scattered light.

We have successfully demonstrated a low-loss all-in-fiber Rayleigh-rejection filter, suitable for spectroscopy of weak Raman scatterers. The broad FWHM bandwidth allows for the transmission of a $3549 \mathrm{~cm}^{-1}$ wavenumber range.

\section{References}

1. M. J. Pelletier, "Fiber optic probe with integral optical filtering" USA Patent no.5862273 (1999).

2. J. Sun, C. C. Chan, X. Y. Dong, "A wide tunable range fiber Bragg grating filter" J. Optoelectron. Adv. M. 8, $1250-1253(2006)$.

3. J. Zhao, M. M. carrabba, F. S. Allen, "Automated fluorescence rejection using shifted excitation Raman difference spectroscopy" Appl. Spectrosc. 56, 834-845 (2002). 